\title{
Early-Onset Complete Ovarian Failure and Lack of Puberty in a Woman With Mutated Estrogen Receptor $\beta$ (ESR2)
}

\author{
Mariarosaria Lang-Muritano, ${ }^{1,2}$ Patrick Sproll, ${ }^{3}$ Sascha Wyss, ${ }^{3}$ Anne Kolly, ${ }^{3}$ \\ Renate Hürlimann, ${ }^{1}$ Daniel Konrad, ${ }^{1,2 *}$ and Anna Biason-Lauber ${ }^{3 *}$ \\ ${ }^{1}$ Division of Pediatric Endocrinology and Diabetology, University Children's Hospital, 8032 Zurich, \\ Switzerland; ${ }^{2}$ Children's Research Center, University Children's Hospital, 8032 Zurich, Switzerland; and \\ ${ }^{3}$ Division of Endocrinology, University of Fribourg, 1700 Fribourg, Switzerland
}

Context: Estrogen resistance due to mutations in the estrogen receptor $\alpha$ gene (ESR1) has been described in men and women and is characterized by osteoporosis, delayed bone age and continuous growth in adulthood, and delayed puberty and multiple ovarian cysts in women. Although mutations in the estrogen receptor $\beta$ gene ESR2 were found in 46, XY patients with differences of sex development, no genetic variants of ESR2 were linked to gonadal defects in women.

Settings and Patient: Here we describe a 16-year-old female patient who came to our tertiary care hospital with complete lack of estrogen action, as demonstrated by absent breast development, primary amenorrhea, and osteoporosis, resembling patients with ESR1 mutation. However, her gonads were clearly abnormal (streak), a finding not observed in ESR1-deficient patients.

Design: To gain insights into the molecular consequences of the ESR2 defect, whole exome sequencing and extensive functional transactivation studies in ovarian, bone, and breast cells were conducted, with or without the natural activator of estrogen receptors, $17 \beta$-estradiol.

Results: We identified a loss-of-function heterozygous mutation of a highly conserved residue in ESR2 that disrupts estradiol-dependent signaling and has a dominant negative effect, most likely due to failure to interact with its coactivator, nuclear coactivator 1 .

Conclusions: This is a report of a loss-of-function mutation in the estrogen receptor $\beta$ in a young woman with complete ovarian failure, suggesting that ESR2 is necessary for human ovarian determination and/or maintenance and that ESR1 is not sufficient to sustain ovarian function in humans. ( $J$ Clin Endocrinol Metab 103: 3748-3756, 2018)

$\mathbf{E}^{\mathrm{s}}$ strogens control development and cell differentiation and in adult organisms maintenance of homeostasis. They do so by binding and activating their nuclear receptors, estrogen receptor $\alpha$ (ESR1) and $\beta$ (ESR2). These receptors bind the same ligands (estradiol and estron) with similar affinity and are almost ubiquitously expressed within the body, so that the tissue distribution and ratio between the two receptors determine the sensitivity and type of reactions of the target tissue to the common ligand. The available data in mice suggest that

$\overline{\text { ISSN Print 0021-972X ISSN Online 1945-7197 }}$

Printed in USA

Copyright (C) 2018 Endocrine Society

Received 10 April 2018. Accepted 27 July 2018.

First Published Online 2 August 2018
ESR2 is a dominant-negative regulator of ESR1dependent transcription in a sort of yin-yang alliance between the two ESRs $(1,2)$. Esr1 knockout mice of both sexes are infertile, and the XX animals had hypoplastic uteri and multicystic ovaries. Heine et al. (1) found that male and female Esr1 knockout mice had hyperplasia and hypertrophy of adipocytes, insulin resistance, and glucose intolerance.

In patients, loss-of-function mutations in ESR1 cause estrogen resistance characterized by osteoporosis, delayed

\footnotetext{
*These authors contributed equally to this study.

Abbreviations: DSD, differences of sex development; E2, $17 \beta$-estradiol; ESR, estrogen receptor; ESR1, estrogen receptor $\alpha$; ESR2, estrogen receptor $\beta$; NCOA1, nuclear coactivator 1; WES, whole exome sequencing; WT, wild-type.
} 
bone age and continuous growth in adulthood, high estrogen blood levels in both sexes (3-5), delayed puberty with no breast development, and infantile uteri and primary amenorrhea and multiple ovarian cysts in women $(4,5)$. In addition, the first male patient displayed insulin resistance and glucose intolerance (3), recapitulating the murine phenotype.

Several animal models of Esr2 deficiency have been created, resulting in various phenotypes (6-8). The first Esr2-deficient mouse model developed normally and was indistinguishable from littermates, had no obvious reproductive phenotype, but had fewer and smaller litters than wild-type (WT) mice; these findings suggest that Esr2 is essential for normal ovulation efficiency but is not essential for female or male sexual differentiation, fertility, or lactation in mice (9). However, the knockout in this model was not complete because alternative transcripts were still processed. Another mouse model of Esr2 knockout with no expression of Esr 2 showed infertility in both male and female animals, without sex reversal (10). In patients, an association between variants of the (CA)n polymorphism and risk for hypospadias was reported (11). More recently, monoallelic and biallelic inactivating mutation in ESR2 has been reported in patients with syndromic and nonsyndromic 46, XY differences of sex development (DSD) (10). In addition, a girl with primary amenorrhea and ESR2 mutation without ovarian dysgenesis was reported by using a candidate single-gene approach that does not exclude the contribution of variants in other genes to the phenotype (12). Here we describe a young woman with a point mutation in ESR2 identified via whole exome sequencing (WES) presenting with streak gonads, absent puberty, no breast development, infantile uterus, osteoporosis, but closed epiphysis.

\section{Case Report}

The patient presented in our clinic at 16.5 years of age with absent breast development, fully developed pubic hair, and primary amenorrhea. She was born in East Africa, grew up in an orphanage, and came to Switzerland at age 15.5 years. She showed a eunuchoid habitus. Her height was $150 \mathrm{~cm}$, weight was $48.1 \mathrm{~kg}$, sitting height was $76.4 \mathrm{~cm}(-4 \mathrm{SD})$, and ratio of sitting height to subischial leg length was $-2.2 \mathrm{SD}$. Blood pressure and heart frequency were within normal limits. She showed no signs of hyperandrogenism, such as acne or hirsutism. Gynecologic examination revealed hypoplastic labia majora, a nonestrogenized infantile vulva with signs of sexual activity, and otherwise normal anatomy.

Bone age was 16 years according to Greulich and Pyle criteria. Abdominal ultrasonography revealed a small infantile uterus. No ovaries could be detected. Dual-energy x-ray absorptiometry showed severe osteoporosis (Z-values: total body, $-4 \mathrm{SD}$; lumbar, L1 to L4, -4.2 ; right femur, -2.2; left femur, -2.2). On initial laboratory examination, serum E2 estradiol level was $59 \mathrm{pmol} / \mathrm{L}$ (normal range, 75 to $392 \mathrm{pmol} / \mathrm{L}$ ), LH was $8.7 \mathrm{U} / \mathrm{L}$ (normal range, 1.1 to $3.8 \mathrm{U} / \mathrm{L}$ ), and FSH was $24.4 \mathrm{U} / \mathrm{L}$ (normal range, 1.4 to $4.2 \mathrm{U} / \mathrm{L}$ ). Her karyotype was 46,XX. Anti-Müllerian hormone was very low at $0.1 \mathrm{pmol} / \mathrm{L}$ (normal, $>8 \mathrm{pmol} / \mathrm{L}$ ). Serum androgen concentrations were within normal range [testosterone, $0.9 \mathrm{nmol} / \mathrm{L}$ (normal range, 0.2 to $1.8 \mathrm{nmol} / \mathrm{L}$ ); androstenedione, $2.6 \mathrm{nmol} / \mathrm{L}$ (normal range, 1.4 to $7.9 \mathrm{nmol} / \mathrm{L}$ ); and dehydroepiandrosterone sulfate, $3.5 \mu \mathrm{mol} / \mathrm{L}$ (normal range, 2.2 to $10 \mu \mathrm{mol} / \mathrm{L})]$. Antiovarian autoantibodies were negative. Thyroid function, prolactin, and hematologic parameters were all within normal limits. Total cholesterol was $5.4 \mathrm{mmol} / \mathrm{L}$ (normal, $<5 \mathrm{mmol} / \mathrm{L}$ ), lowdensity lipoprotein cholesterol was $3.8 \mathrm{mmol} / \mathrm{L}$ (nor$\mathrm{mal},<3 \mathrm{mmol} / \mathrm{L}$ ), high-density lipoprotein cholesterol was $1.2 \mathrm{mmol} / \mathrm{L}$ (normal, $>1 \mathrm{mmol} / \mathrm{L}$ ), and triglycerides were $0.8 \mathrm{mmol} / \mathrm{L}$ (normal, $<2.0 \mathrm{mmol} / \mathrm{L}$ ). Homeostasis model assessment index was 0.7 (normal, $<3.5 \mathrm{nmol} / \mathrm{L}$ ) and 25-hydroxy vitamin D3 was $43.3 \mathrm{nmol} / \mathrm{L}$ (normal, $>50 \mathrm{nmol} / \mathrm{L}$ ) (Supplemental Table 1).

She was started on transdermal estrogen therapy with an initial dose of $12.5 \mu \mathrm{g}$. She showed signs of breast development around 3 weeks after initiation of transdermal estradiol application. Estradiol dose was sequentially increased and eventually switched after 6 months to a cyclic transdermal E2/progesterone preparation. Menarche appeared after the first month of cyclic hormone replacement, followed by regular menses. A combination therapy with calcium and vitamin D was introduced because of low bone density. The 2-year follow-up under treatment with estrogen and calcium/ vitamin D3 showed a change of bone density (Z-values: total body, $-3.3 \mathrm{SD}$; lumbar L1 to $\mathrm{L} 4,-3.3$; right femur, -1.8 ; left femur, -1.9 ), but the values are still abnormal and require a long-term reevaluation.

Ultrasonography under estrogen replacement therapy revealed stimulated endometrium and increased uterus volume of $8 \mathrm{~mL}$. Ovaries could now be identified but appeared as streaks without follicles (Supplemental Fig. 1). Tables 1 and 2 summarize clinical and laboratory data and compare them to those of the ESR1-deficient patients.

Informed written consent was obtained, and WES analysis was performed.

\section{Materials and Methods}

\section{WES}

Genomic DNA samples from the patient were analyzed by WES on a SureSelect Human All Exon V.6.0 capture kit (Agilent Technologies, Santa Clara, CA) and a HiSeq 4000 Sequencer (Illumina, San Diego, CA). The reads were screened 


\section{Table 1. Clinical Comparison Between ESR1 and ESR2 Defects}

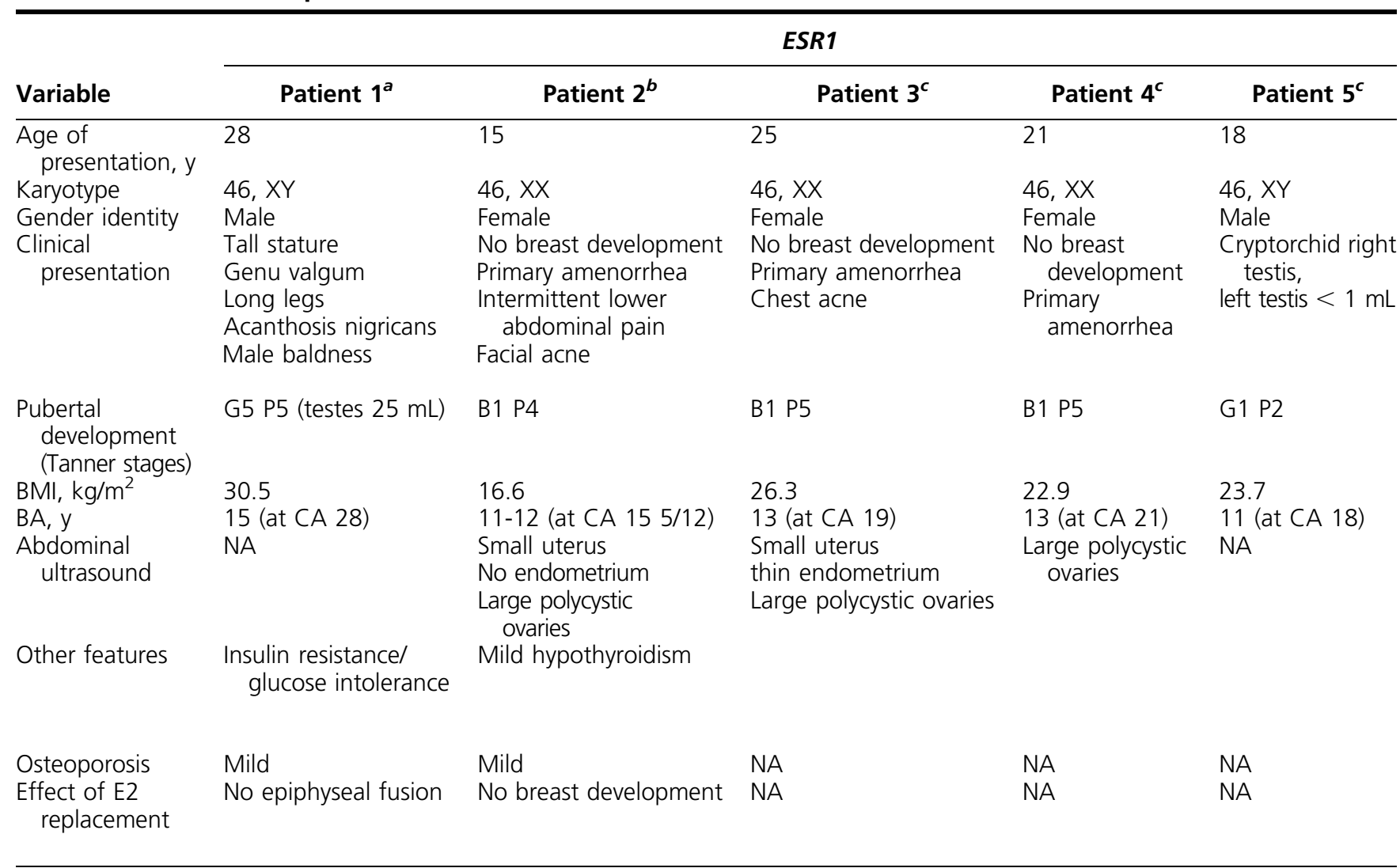

with FastQ Screen (Babraham Bioinformatics, Cambridge, United Kingdom) for possible contamination, and a quality control has been performed with FastQC (Babraham Bioinformatics). Read alignment has been performed with Bowtie 2 (Johns Hopkins University, Baltimore, MD) against a human reference sequence (GRCh37.p13/hg19). GATK HaplotypeCaller (Broad Institute, Cambridge, MA) was used for calling single-nucleotide polymorphisms and indels, and the aligned data were visualized with the Integrative Genomics Viewer (Broad Institute). The filtering of candidate variants by frequency and prediction of intolerance to loss of function was analyzed by using the ExAC browser (Exome Aggregation Consortium, Broad Institute).

\section{ESR2-targeted mutational analysis}

Genomic DNA was extracted from peripheral blood leukocytes (Qiagen DNA blood and cell culture kit; Qiagen $\mathrm{GmbH}$, Hilden, Germany). All exons from ESR2 (RefSeqNG_011535.1), including the intronic regions, were amplified and sequenced with ESR2-specific primers (Supplemental Table 2). Direct sequencing of the polymerase chain reaction products was performed with the use of the ABI Prism BigDye Terminator Cycle Sequencing Ready Reaction Kit (Applied Biosystems, Life Technologies Corp., Austin, TX) and analyzed with the use of the 3500 Series Genetic Analyzer (Applied Biosystems, Carlsbad, CA).

\section{Protein model and in silico mutagenesis of ESR2}

The three-dimensional model of the ESR2-ligand binding domain sequence (amino acids 261 to 500) was built by referring to the crystal structure of ESR2 (3OLL) as a template and by using the program YASARA (YASARA Biosciences $\mathrm{GmbH}$, Vienna, Austria). In silico mutagenesis was performed to create the K314R mutation by using the mutagenesis tool from PyMOL (Schrödinger, New York, NY). The models were refined with a 1000 ps molecular dynamics simulation by using an Assisted Model Building with Energy Refinement 2003 force field. Finally, both models were checked with the programs ERRAT (University of California, Los Angeles, Los Angeles, CA), RAMPAGE (University of Cambridge, Cambridge, United Kingdom), and Verify3D (13). The structures were depicted by using PyMOL (Schrödinger).

\section{Site-directed mutagenesis}

The site-directed mutation of Lys314 to arginine was introduced in a green fluorescent protein-tagged cDNA clone ESR2 (NM_001437) from OriGene (OriGene Technologies, Rockville, MD). The mutation was performed by using the QuikChange Site-Directed Mutagenesis Kit (Agilent Technologies) according to the manufacturer's instructions. The mutagenic oligonucleotides used are shown in Supplemental Table 3.

Thermocycler conditions for the single amino acid mutation were as follows: $95^{\circ} \mathrm{C}$ for 2 minutes, 18 cycles of $95^{\circ} \mathrm{C}$ for 30 seconds, $55^{\circ} \mathrm{C}$ for 1 minute, followed by $68^{\circ} \mathrm{C}$ for 8 minutes, with a final extension at $68^{\circ} \mathrm{C}$ for 10 minutes. The resulting mutant plasmids were verified by DNA sequencing. 
Table 1. Clinical Comparison Between ESR1 and ESR2 Defects (Continued)

\begin{tabular}{|c|c|c|c|}
\hline \multicolumn{4}{|c|}{ ESR2 } \\
\hline Patient $6^{d}$ & Patient $7^{d}$ & Patient $8^{d}$ & Current Patient \\
\hline $46, X Y$ & $46, X Y$ & $46, X Y$ & $46, X X$ \\
\hline Female & Female & Female & Female \\
\hline B1 P3 & NA & B1 P4 & B1 P4 \\
\hline $\begin{array}{l}\text { Large cyst at the right adnexal } \\
\text { region containing } \\
\text { Wolffian remnants }\end{array}$ & & Infantile uterus & No visible gonads \\
\hline Anal atresia & & & No insulin resistance \\
\hline \multicolumn{4}{|l|}{$\begin{array}{l}\text { Blepharophimosis, ptosis, } \\
\text { nystagmus, severe myopia, } \\
\text { dysmorphic features }\end{array}$} \\
\hline NA & NA & NA & Severe \\
\hline B5 & NA & NA & $\begin{array}{l}\text { B5 P5; menarche; uterus } 8 \mathrm{~mL} \\
\text { Streak gonads, volume } \\
\quad 0.5-1 \mathrm{~mL} \text { without follicles }\end{array}$ \\
\hline
\end{tabular}

Abbreviations: BA, bone age; CA, chronological age; NA, not available; SH, standing height; SILL, subischial leg length.

${ }^{a}$ Reference 3 .

${ }^{b}$ Reference 4 .

'Reference 5 .

${ }^{d}$ Reference 10 .

\section{Cell culture and transfection}

The human female breast adenocarcinoma cell line MCF-7 and the osteosarcoma cell line U2-OS (female) were cultured in DMEM and the human ovarian granulosa-like tumor cell line (female), KGN in DMEM/ F-12 media (Sigma-Aldrich, St. Louis, MO) supplemented with $10 \%$ newborn calf serum, $100 \mathrm{U} / \mathrm{mL}$ penicillin, and $100 \mu \mathrm{g} / \mathrm{mL}$ streptomycin. For transient transfection assays, MCF-7, U2-OS, and KGN were plated in six well plates and grown up to $60 \%$ to $70 \%$ confluence before transfection with the use of Metafectene (Biontex Laboratories, München, Germany). Each well was transfected with a total of $1 \mu \mathrm{g}$ DNA for 48 hours, washed with PBS before being lysed, and collected for assessment.

\section{Transactivation assay}

We contransfected $500 \mathrm{ng} /$ well of the luciferase reporters from the ERE Reporter Assay Kit (Qiagen GmbH) with the ESR constructs by using Metafectene. Forty-eight hours later, cells were lysed and luciferase assays were performed by using a Dual-Luciferase ${ }^{\circledR}$ Reporter Assay System (Promega, Madison, WI) on a single-tube luminometer LB9508 Lumat3 (Berthold Technologies, Bad Wildbad, Germany) following the manufacturer's protocol. Transfection of each construct was performed in triplicate in each assay, and a total of three assays were performed on 3 separate days. The results are expressed as the mean \pm SEM of the independent experiments.

\section{Ligand (E2) dose response}

The cells were transfected as described for the luciferase assay above with ESR2 WT or ESR2 mutant in duplicates. The medium was replaced the next day with medium containing $10^{-12}, 10^{-10}, 10^{-9}, 10^{-8}, 10^{-7}$, or $10^{-6}$ mole E2. Again, 24 hours later, the cells were washed with $1 \times$ PBS before being lysed and collected for assessment using the Dual-Luciferase ${ }^{\circledR}$ Reporter Assay System as described above. Transfection of each construct was performed in duplicates in each assay and a total of three assays were performed on three separate days. The results are the mean \pm SEM of independent experiments.

\section{Immunofluorescence}

Cells grown on cover slips were transfected as described above. Forty-eight hours later, the cells were fixed with $4 \%$ formaldehyde (wt/vol) in $1 \times$ PBS for 15 minutes at room temperature. Cover slips were mounted with Vectrashield (Vector Laboratories, Inc., Burlingame, CA) containing 4',6diaminidino-2-phenylindole. Images were acquired by using a Nikon eclipse NI-E microscope system. 
Table 2. Comparison of Endocrine Profiles Between ESR1- and ESR2-Deficient Patients

\begin{tabular}{|c|c|c|c|c|c|c|c|c|c|}
\hline Variable & \multicolumn{5}{|c|}{ ESR1 } & \multicolumn{4}{|c|}{ ESR2 } \\
\hline $\begin{array}{l}\text { Age of } \\
\text { presentation, y }\end{array}$ & 28 & 15 & 25 & 21 & 18 & 15 & 12.5 & 24 & 16.5 \\
\hline Karyotype & $46, X Y$ & $46, X X$ & $46, X X$ & $46, x X$ & $46, X Y$ & $46, X Y$ & $46, X Y$ & $46, X Y$ & $46, x X$ \\
\hline $\begin{array}{l}\text { Gender identity } \\
\text { Estrone (E1) }\end{array}$ & $\begin{array}{c}\text { Male } \\
\uparrow \uparrow\end{array}$ & $\begin{array}{c}\text { Female } \\
\uparrow \uparrow \uparrow\end{array}$ & $\begin{array}{l}\text { Female } \\
\text { NA }\end{array}$ & $\begin{array}{l}\text { Female } \\
\text { NA }\end{array}$ & $\begin{array}{l}\text { Male } \\
\text { NA }\end{array}$ & $\begin{array}{l}\text { Female } \\
\text { NA }\end{array}$ & $\begin{array}{l}\text { Female } \\
\text { NA }\end{array}$ & $\begin{array}{l}\text { Female } \\
\text { NA }\end{array}$ & \\
\hline Estradiol (E2) & $\uparrow \uparrow$ & $\uparrow \uparrow \uparrow$ & $\uparrow \uparrow \uparrow$ & $\uparrow \uparrow \uparrow$ & $\mathrm{n}$ & $\begin{array}{l}\text { Unknown } \\
\text { Likely } \downarrow\end{array}$ & $\begin{array}{l}\text { Unknown } \\
\text { Likely } \downarrow\end{array}$ & $\begin{array}{l}\text { Unknown } \\
\text { Likely } \downarrow\end{array}$ & $\begin{array}{c}111 \mathrm{pmol} / \mathrm{L}(\mathrm{NV}, 75-392) \\
\downarrow \\
59 \mathrm{pmol} / \mathrm{L}(\mathrm{NV}, 110-375)\end{array}$ \\
\hline LH & $\uparrow$ & N & $\uparrow$ & $\uparrow$ & $\uparrow \uparrow$ & $\uparrow$ & $\uparrow$ & $\uparrow$ & $8.7 \mathrm{U} / \mathrm{i}(\mathrm{NV}, 1.1-3.8)$ \\
\hline FSH & $\uparrow \uparrow$ & $N-\uparrow$ & $\uparrow$ & $\uparrow$ & $\uparrow \uparrow$ & $\uparrow \uparrow \uparrow$ & $N$ & $\uparrow \uparrow$ & $24.4 \mathrm{U} / \mathrm{i}(\mathrm{NV}, 1.4-4.2)$ \\
\hline Inhibin B & NA & N (for Tanner 1) & $\uparrow \uparrow$ & NA & NA & $\downarrow \downarrow$ & NA & NA & $<7 \mathrm{pg} / \mathrm{mL}(\mathrm{NV}, 10-200)$ \\
\hline $\mathrm{AMH}$ & & N & N & NA & NA & $\downarrow \downarrow$ & NA & NA & $0.2 \mathrm{pmol} / \mathrm{L}(\mathrm{NV}>\mathrm{s})$ \\
\hline
\end{tabular}

Abbreviations: DXA, dual-energy x-ray absorptiometry; N, normal; NA, not available; NV, normal value; $\downarrow$ slightly decreased; $\downarrow \downarrow$ mildly decreased; $\downarrow \downarrow \downarrow$ highly decreased; $\uparrow$ slightly increased; $\uparrow \uparrow$ mildly increased; $\uparrow \uparrow \uparrow$ highly increased.

${ }^{a}$ Reference 3.

${ }^{b}$ Reference 4.

${ }^{\mathrm{c}}$ Reference 5.

${ }^{d}$ Reference 10 .

\section{Western blot}

Western blot analysis was performed according to standard procedures using the monoclonal mouse anti-green fluorescent protein antibody (Antiturbo GFP Monoclonal Antibody TA 150041, OriGeneTechnologies), diluted at 1:2000, as first antibody and the anti-mouse antibody peroxidase (NIF825), diluted at 1:5000, as secondary antibody. The antibody against $\alpha$ tubulin, GT 114 (GTX628802, GeneTex, Inc. Irvine, CA), was used as control for amount and quality of the proteins.

\section{Results}

WES identified a heterozygous missense mutation- $\mathrm{a}$ transition from A to G-in the fifth coding exon of ESR2 (NM 001040275.1:c.941A $>$ G, on protein level: p.Lys314Arg) that was confirmed by targeted Sanger sequencing (Supplemental Fig. 2A). Of note, lysine 314 is an evolutionary highly conserved residue (Supplemental Fig. 2B).

Although DNA of parents is not available (the patient is an orphan East African refugee), the mutation was not found in ExAc database or in 300 controls, including 15 race-matched controls, and is predicted to be pathogenic (Sorting Intolerant From Tolerant score, 0.01: deleterious; Polymorphism Phenotyping score, 0.999: probably damaging).

WES allowed us to examine variations in 85 genes known to be implicated in 46,XY and 46,XX DSD (14) as a filtering tool with the help of the Integrative Genomics Viewer (Supplemental Table 4). We discovered multiple heterozygote and homozygote variants in additional genes apart from ESR2. However, these variants were very common polymorphisms found with a high frequency in the general population (ExAC) (15) or were predicted to be benign variants by Polymorphism Phenotyping and Sorting Intolerant From Tolerant.

We also did not find any pathogenic variant in other genes known to be related to premature ovarian failure (Supplemental Table 5). To further expand the list of possible targets, we identified factors linked to ESR signaling, including ESR1, using Pathway Studio software (Elsevier, New York, NY) and again found no mutation predicted to be relevant for disease (Supplemental Fig. 3; Supplemental Table 6).

To gain more insights into the mechanism of disease, we performed molecular modeling of the mutant ESR2. The substitution of the highly conserved lysine with an arginine at position 314 was predicted to impair the interaction of the mutant ESR2 with nuclear coactivator 1 (NCoA1) (Fig. 1).

Transactivation studies of an estrogen-responsive element-dependent luciferase reported gene were conducted in three cell types, modeling three sites of estrogen action apparently affected in our patient: the ovarian KGN, the breast MCF7, and the bone U2OS 

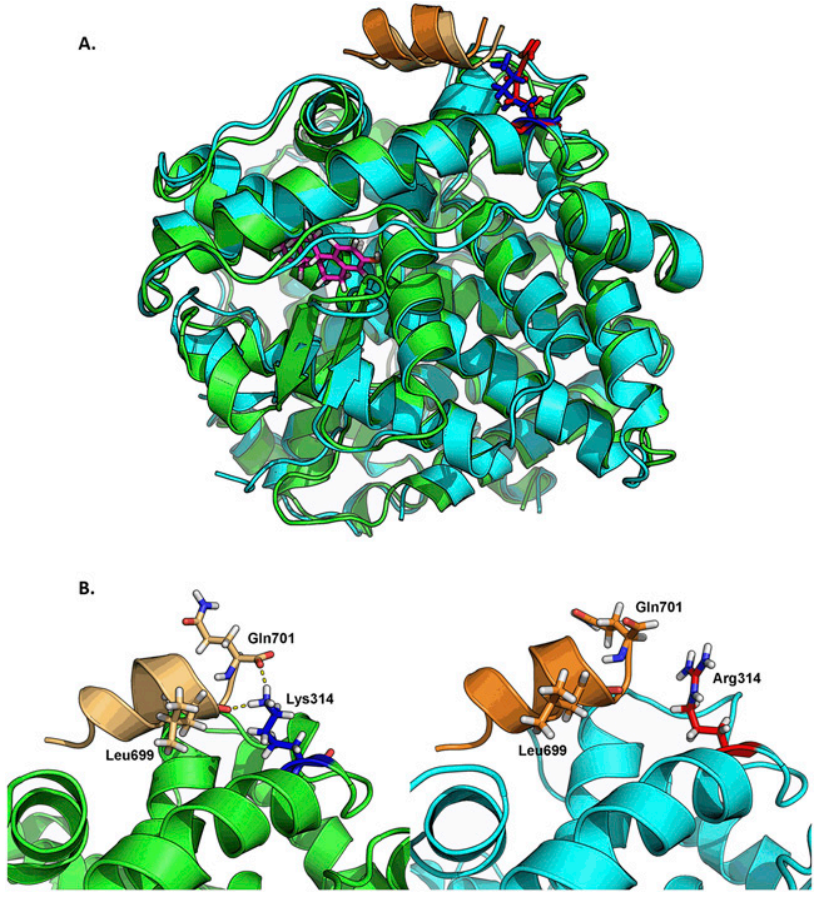

Figure 1. Molecular modeling of WT and mutant ESR2. Superimposition of WT-ESR2 (green) and ESR2-K314R (cyan) protein models (ligand binding domain), shown as ribbon diagrams. The residues of 314 are shown as stick models, the WT residue in blue, and the mutant residue in red. The $\alpha$ helices depicted in orange (light, WT; dark, mutant) are fragments of the ESR cofactor NCOA1. The K314R mutation leads to a change in the binding site of NCoA1. (A) Bound estrogen is depicted as a stick model in pink. The NCOA1 binding site is compared between WT (green) and mutant (cyan) models. (B) The WT Lys314 potentially participates in the binding of the cofactor, through polar contact (yellow dots) with the amino acids Leu699 and Gln701 of NCOA1. In the mutant model, the polar contact at this amino acid positions is lost because of the mutant Arg314. This in turn might lead to a diminished or lost interaction between ESR2 and its cofactor NCOA1.

cells. In KGN pregranulosa cells, the mutant ESR2 has a transactivation capacity similar to that of negative control (empty vector)-that is, it is unable to drive the expression of the luciferase reporter gene and has a significant dominant negative influence on its WT counterpart (Fig. 2A), which is in agreement with the heterozygote state. ESR1 was not tested in these cells because ESR2 is the predominant estrogen receptor in granulosa cells of the developing gonad (16-18). The transcriptional activity of the mutant ESR2 was not rescued by increasing quantities of the natural ligand $17 \beta$-estradiol (E2) (Fig. 2A), suggesting a complete loss of function.

In MCF7 breast and U2OS bone cells, the mutant ESR2 was completely inactive and had a dominant negative effect on the otherwise very active WT ESR2 (Fig. 2B). Coexpression of ESR1 and ESR2 significantly reduced ESR2-dep transactivation without altering and increasing ESR1 activity in MCF7 and
U2OS bone cells, respectively (Fig. 2C), contradicting the hypothesis that ESR2 modulates/decreases ESR1mediated gene transcription in mice (2). When challenged with E2, the mutant ESR2 in breast cells had a much lower basal transactivation potential than the WT receptor, but it showed a partial rescue at higher E2 dose. In osteoblasts, the E2 dose response curve showed a reduced transactivation capacity of the mutant ESR2, which is partially rescued under higher E2 dose.

Protein quantity, stability, and nuclear localization of overexpressed mutant ESR2 in breast, bone, and granulosa cells (MCF7, U2OS, and KGN cells, respectively) were similar to those of to WT protein (Supplemental Fig. 4 and 5).

\section{Discussion}

Here we describe a 16-year-old adolescent who presented with complete lack of breast development, infantile uterus, and primary amenorrhea as well as severe osteoporosis, all suggestive of a defective estrogen action. Her phenotype resembled that of 46, XX ESR1-deficient patients (3-5), with some notable differences (Table 1): Her bone age was adult rather than the delayed bone age and continuous growth of the ESR 1 patients, her androgens were normal, and her estrogens were low (and not massively elevated as in the ESR1-deficient cases). Her ovaries were not visible at ultrasound, in contrast to the enlarged multicystic ovaries of the ESR1 patients, and markers of granulosa cell health, such as Anti-Müllerian hormone and inhibin B, were unmeasurable, suggesting absence of follicles/streak gonads. Furthermore, under exogenous estrogens, the patient developed breast and uterine maturation and (with the addition of progestin) menstrual bleeding, in contrast to the ESR1-defective cases.

Taking advantage of next-generation sequencing approaches, we identified a point mutation in ESR2 leading to the exchange of an evolutionary highly conserved lysine to an arginine, predicted to be deleterious. Although the patient's parents were not available for examination (the patient is an orphan East African refugee), the mutation was not found in any of the known single-nucleotide polymorphism databases (although no extensive genetic database of sub-Saharan population exists) or in 300 controls, including a small number of race-matched individuals. The unbiased WES approach did not show any other relevant variation in gonadal development/DSD/premature ovarian insufficiency genes or in genes linked to ESR signaling, including ESR1. Molecular modeling of the mutated 
A.
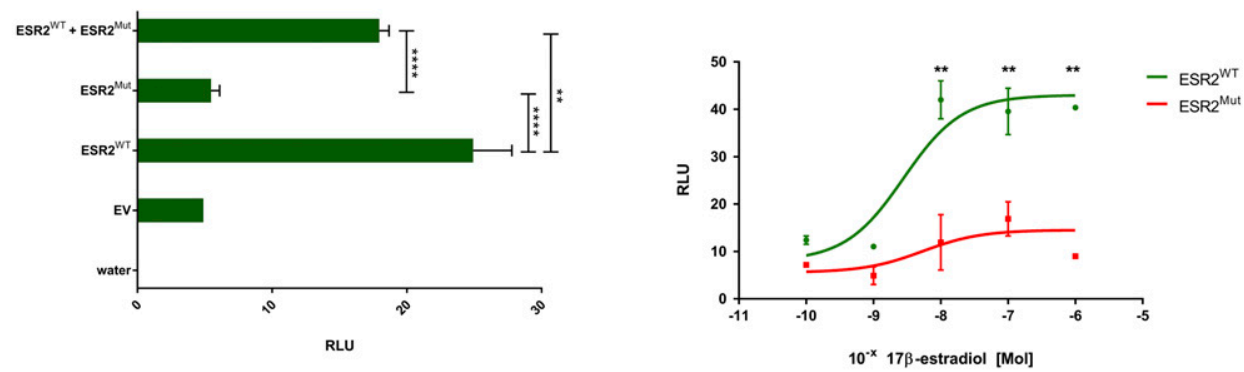

B.
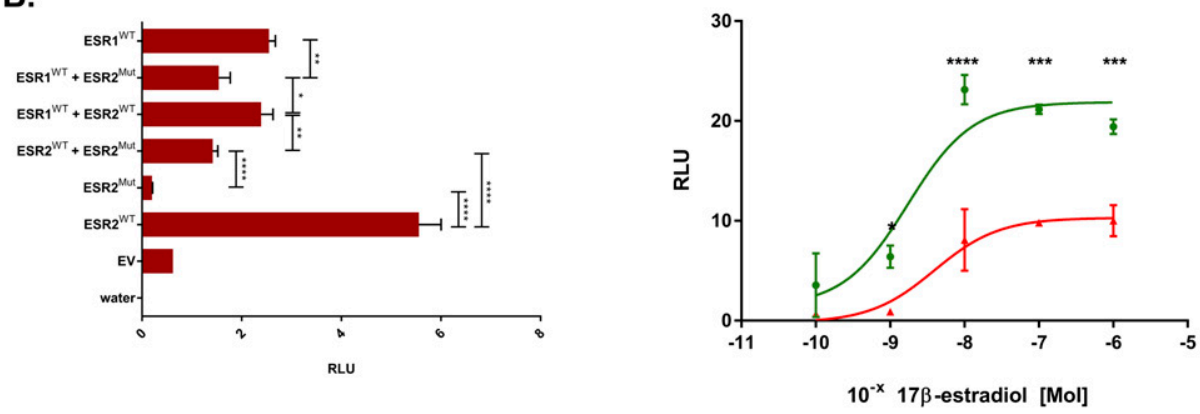

C.
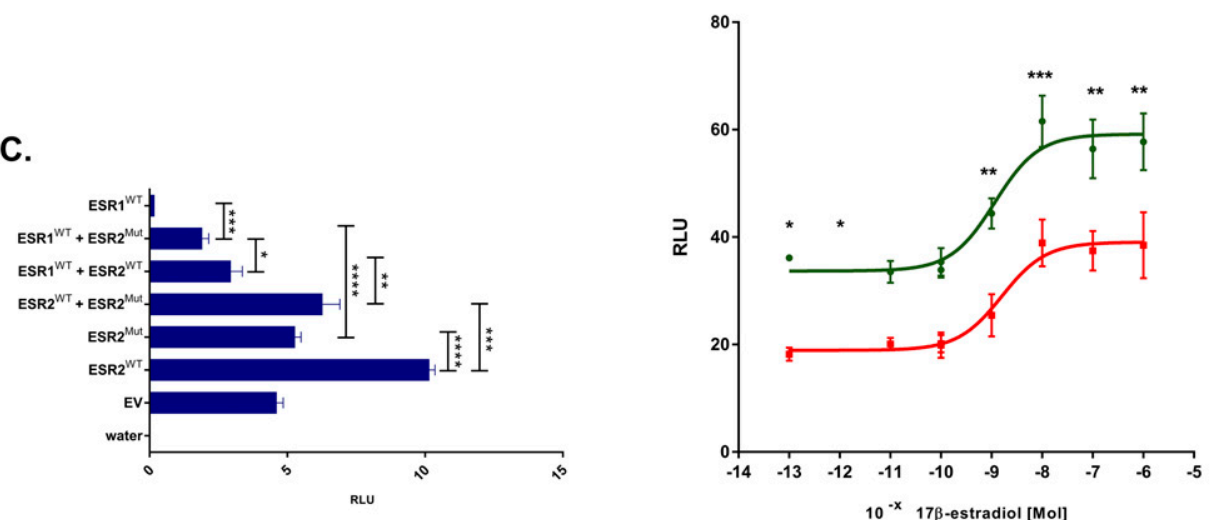

Figure 2. Reduced estrogen receptor activity. Transactivation of an estrogen responsive element (ERE) upstream of the luciferase construct revealed greatly reduced activity (measured as relative light units, RLU) by the mutated ESR2 (ESR2 ${ }^{\text {Mut }}$ ) Compared with WT $\left(E S R 2{ }^{W T}\right.$ ), without rescue under treatment with increasing concentrations of the natural ligand E2 in (A) pregranulosa KGN cells, (B) breast MCF cells, or osteoblast-like U2OS cells. In almost all cases, ESR2 ${ }^{\text {Mut }}$ had a dominant negative effect over the normal ESR2 and ESR1 receptors (ESR2 ${ }^{\mathrm{WT}}$, ESR1 ${ }^{\mathrm{WT}}$ ). In (C) bone cells the combination of mutant ESR2 (ESR2 ${ }^{\mathrm{Mut}}$ ) with the normal ESR1 (ESR1 ${ }^{\mathrm{WT})}$ seemed to increase the activity of the latter. The results are represented as mean \pm SD of three independent experiments. Significance was calculated by using an unpaired $t$-test. ${ }^{*} * * P<0.0001 ; * * * P<0.001 ;{ }^{*} * P<0.01 ;{ }^{*} P<0.05$. Abbreviation: EV, empty vector; water, mock transfection.

ESR2 suggested that its interaction with the transcriptional regulator NCoA1 might be impaired. NCoA1 interacts with and enhances the transcriptional activity of several nuclear receptors, including progesterone, androgen, estrogen, glucocorticoid, thyroid, and retinoid X receptors. NCoA1 is recruited to DNA promotion sites by ligand-activated nuclear receptors $(19,20)$. NCoA1, in turn, acetylates histones, which makes downstream DNA more accessible to transcription factors. Hence, NCoA1 assists nuclear receptors in the upregulation of DNA expression.

Although the mutation did not impair protein stability or nuclear localization, it did significantly impair
ESR2 signaling. To analyze the effects of mutation in different estrogen-responsive tissues, we studied the effect on ESR-dependent signaling in ovarian, breast, and bone cells.

In the ovary, ESR2 is the dominantly expressed ESR in the granulosa cells of the small growing and preovulatory follicles and ESR1 much less or not at all in various species $(16-18,21)$, and in the human fetal ovary during the ninth to the 15-16th gestational week, a time crucial for gonadal development (E. Lecluze, personal communication). The description of 46, XY patients with DSD, gonadal dysgenesis, and mutations in ESR2 (10) demonstrated an unexpected role for ESR 2 in testis formation 
and suggested a possible function of $\operatorname{ESR} \beta$ in early gonadal development, which was not seen in the first mouse model. More recently, another mouse model of Esr2 knockout with no expression of Esr2 showed infertility in both male and female animals (10). In our case, the mutated ESR2 completely lost its function in the pregranulosa cell system, showed a dominant negative effect on the normal receptor (which may account for the haploinsufficiency), and was not stimulated by exogenous estradiol.

The effect of the ESR2 mutation on mammary and uterine development is unclear because of the inadequate estrogen production by the failing ovaries. The prompt response of breast and uterine tissue to exogenous estrogens confirms that ESR 1 is sufficient and necessary to stimulate breast and endometrial growth.

The explanation of the bone phenotype is more challenging: Although the severe osteoporosis is compatible with estrogen deficiency (due to the gonadal failure) and/or estrogen resistance (due to ESR2 mutation), the epiphyseal closure in the absence of estrogen production is difficult to account for. To further complicate the issue, there are conflicting reports on the localization and function of ESR 1 and ESR2 in growth plate chondrocytes, with some studies identifying predominantly ESR1 (22) and others, ESR2 (23) or both ESR1 and ESR2 (24), in the hypertrophic zone.

In our functional studies, the mutant ESR2 seemed to increase the transactivation potential of ESR1 in bone, perhaps via an increased availability of NCoA1, set free by the mutant ESR 2 that cannot efficiently recruit it. On the other hand, in our expression studies, normal WT ESR2 seemed to work in bone cells at very low concentration of E2 $(0.1 \mathrm{pmol})$, mirroring the estrogen levels measured in our patient, and is not affected by mutant ESR2: Bone maturation/epiphyseal closure in our patient might have been stimulated by low levels of estrogen derived by the peripheral conversion of adrenal androgen precursors. On the other hand, given the very low estradiol levels to be expected in this patient, a ligandindependent ESR activation (25) might partly contribute to these effects.

The 2-year follow up under estrogen (with calcium/ vitamin D) treatment showed a promising but much less notable improvement of bone density parameters (compared with breast and uterus), again suggesting a more complex or slower influence of estrogens on bone health/homeostasis.

The role of ESR2 in the regulation of the hypothalamus/pituitary/gonadal axis is unclear. Although adult GnRH neurons express ESR2 but not ESR1 in all species studied, targeted deletion of ESR2 does not alter E2-mediated GnRH expression in these neurons, suggesting that a direct action of estrogens through ESR2 remains to be elucidated $(26,27)$. In our patient, the elevated basal gonadotropins were due to primary hypogonadism (lack of estrogen negative feedback) and suggest that ESR2 is not necessary for FSH/LH secretion, mirroring the findings in the 46, XY DSD patients (10). Nevertheless, because FSH levels were expected to be higher, a partial effect on the hypothalamus/ pituitary/gonadal axis and gonadotropins secretion cannot be excluded.

Estrogens are involved in neurogenesis, and clinical as well as experimental evidence supports their protective effect against neurodegenerative diseases, such as Alzheimer and Parkinson disease (28-30). In Esr2-deficient female mice, Krezel and coworkers (31) observed a behavior consistent with increased anxiety and concluded that, particularly in females, there is an important role for Esr2-mediated estrogen signaling in the processing of emotional behavior. Furthermore, Rissman et al. (32) showed that E2 affects learning and memory via Esr2 in mice. In our illiterate patient, we did not observe any neurologic deficit, but she seems to have a learning disability. She has not yet learned to read. Her behavior was quite inconspicuous. Thus, the role of ESR2 in the central nervous system in humans still needs further investigation.

The discovery of ESR2 by Gustafsson and coworkers (33) opened the way to a deeper understanding of the complex and multiple actions of estrogens, showing that it is not the ligand but the relationship between the two receptors that determines the variety of estrogen effects. Here we describe a young woman in whom a loss-of-function mutation in the $\operatorname{ESR} \beta$ led to early-onset complete ovarian insufficiency, suggesting that ESR2 is necessary for early human ovarian development and/or maintenance and that ESR1 is not sufficient to support ovarian function in women. It remains to be established whether estrogen resistance due to milder defects in ESR2 might account for unexplained cases of premature ovarian failure or infertility.

\section{Acknowledgments}

Financial Support: The work was supported by grant 320030_ 160334 from the Swiss National Science Foundation (A.B.L.).

Correspondence and Reprint Requests: Anna BiasonLauber, MD, Division of Endocrinology, University of Fribourg, Chemin du Musée 5, 1700 Fribourg, Switzerland. E-mail: anna.lauber@unifr.ch; or Daniel Konrad, MD, PhD, Division of Pediatric Endocrinology and Diabetology, University Children's Hospital, 8032 Zurich, Switzerland. E-mail: daniel.konrad@kispi.uzh.ch. 
Disclosure Summary: The authors have nothing to disclose.

\section{References}

1. Korach KS. Insights from the study of animals lacking functional estrogen receptor. Science. 1994;266(5190):1524-1527.

2. Lindberg MK, Movérare S, Skrtic S, Gao H, Dahlman-Wright K, Gustafsson JA, Ohlsson C. Estrogen receptor (ER)-beta reduces ERalpha-regulated gene transcription, supporting a "ying yang" relationship between ERalpha and ERbeta in mice. Mol Endocrinol. 2003;17(2):203-208.

3. Smith EP, Boyd J, Frank GR, Takahashi H, Cohen RM, Specker B, Williams TC, Lubahn DB, Korach KS. Estrogen resistance caused by a mutation in the estrogen-receptor gene in a man. N Engl J Med. 1994;331(16):1056-1061.

4. Quaynor SD, Stradtman EW Jr, Kim HG, Shen Y, Chorich LP, Schreihofer DA, Layman LC. Delayed puberty and estrogen resistance in a woman with estrogen receptor $\alpha$ variant. $N$ Engl J Med. 2013;369(2):164-171.

5. Bernard V, Kherra S, Francou B, Fagart J, Viengchareun S, Guechot J, Ladjouze A, Guiochon-Mantel A, Korach KS, Binart N, Lombes M, Christin-Maitre S. Familial multiplicity of estrogen insensitivity associated with a loss-of-function ESR1 mutation. J Clin Endocrinol Metab. 2016;102(1):93-99.

6. Dupont S, Krust A, Gansmuller A, Dierich A, Chambon P, Mark M. Effect of single and compound knockouts of estrogen receptors alpha (ERalpha) and beta (ERbeta) on mouse reproductive phenotypes. Development. 2000;127(19):4277-4291.

7. Korach KS, Emmen JM, Walker VR, Hewitt SC, Yates M, Hall JM, Swope DL, Harrell JC, Couse JF. Update on animal models developed for analyses of estrogen receptor biological activity. J Steroid Biochem Mol Biol. 2003;86(3-5):387-391.

8. Cacioppo JA, Koo Y, Lin PC, Osmulski SA, Ko CD, Ko C. Generation of an estrogen receptor beta-iCre knock-in mouse. Genesis. 2016;54(1):38-52.

9. Krege JH, Hodgin JB, Couse JF, Enmark E, Warner M, Mahler JF, Sar M, Korach KS, Gustafsson JA, Smithies O. Generation and reproductive phenotypes of mice lacking estrogen receptor beta. Proc Natl Acad Sci USA. 1998;95(26):15677-15682.

10. Baetens D, Guran T, Mendonca BB, Gomes NL, De Cauwer L, Peelman F, Verdin H, Vuylsteke M, Van der Linden M, Esr2 Study Group, Atay Z, Bereket A, de Krijger RR, Preter K, Domenice S, Turan S, Stoop H, Looijenga LH, De Bosscher K, Cools M, De Baere E. Biallelic and monoallelic ESR2 variants associated with 46,XY disorders of sex development. Genet Med. 2018;20(7):717-727.

11. Beleza-Meireles A, Kockum I, Lundberg F, Söderhäll C, Nordenskjöld A. Risk factors for hypospadias in the estrogen receptor 2 gene. J Clin Endocrinol Metab. 2007;92(9):3712-3718.

12. Asadi M, Ghafouri-Fard S, Zare-Abdollahi D, Ebrahim-Habibi A, Matin N. Estrogen receptor mutation in a girl with primary amenorrhea. Clin Genet. 2013;83(5):497-498.

13. Bowie JU, Lüthy R, Eisenberg D. A method to identify protein sequences that fold into a known three-dimensional structure. Science. 1991;253(5016):164-170.

14. Baetens D, Stoop H, Peelman F, Todeschini AL, Rosseel T, Coppieters F, Veitia RA, Looijenga LH, De Baere E, Cools M. NR5A1 is a novel disease gene for 46,XX testicular and ovotesticular disorders of sex development. Genet Med. 2017; 19:367-376.

15. Lek M, Karczewski KJ, Minikel EV, Samocha KE, Banks E, Fennell T, O'Donnell-Luria AH, Ware JS, Hill AJ, Cummings BB, Tukiainen T, Birnbaum DP, Kosmicki JA, Duncan LE, Estrada K, Zhao F, Zou J, Pierce-Hoffman E, Berghout J, Cooper DN, Deflaux N, DePristo M, Do R, Flannick J, Fromer M, Gauthier L, Goldstein J, Gupta N, Howrigan D, Kiezun A, Kurki MI, Moonshine AL, Natarajan P, Orozco L, Peloso GM, Poplin R, Rivas MA, RuanoRubio V, Rose SA, Ruderfer DM, Shakir K, Stenson PD, Stevens C, Thomas BP, Tiao G, Tusie-Luna MT, Weisburd B, Won HH, Yu D,
Altshuler DM, Ardissino D, Boehnke M, Danesh J, Donnelly S, Elosua R, Florez JC, Gabriel SB, Getz G, Glatt SJ, Hultman CM, Kathiresan S, Laakso M, McCarroll S, McCarthy MI, McGovern D, McPherson R, Neale BM, Palotie A, Purcell SM, Saleheen D, Scharf JM, Sklar P, Sullivan PF, Tuomilehto J, Tsuang MT, Watkins HC, Wilson JG, Daly MJ, MacArthur DG; Exome Aggregation Consortium. Analysis of protein-coding genetic variation in 60,706 humans. Nature. 2016;536(7616):285-291.

16. Byers M, Kuiper GG, Gustafsson JA, Park-Sarge OK. Estrogen receptor-beta mRNA expression in rat ovary: down-regulation by gonadotropins. Mol Endocrinol. 1997;11(2):172-182.

17. Słomczyńska M, Duda M, Galas J. Estrogen receptor alpha and beta expression in the porcine ovary. Folia Histochem Cytobiol. 2001;39(2):137-138.

18. Pelletier G, El-Alfy M. Immunocytochemical localization of estrogen receptors alpha and beta in the human reproductive organs. J Clin Endocrinol Metab. 2000;85(12):4835-4840.

19. Onate SA, Boonyaratanakornkit V, Spencer TE, Tsai SY, Tsai MJ, Edwards DP, O'Malley BW. The steroid receptor coactivator-1 contains multiple receptor interacting and activation domains that cooperatively enhance the activation function 1 (AF1) and AF2 domains of steroid receptors. J Biol Chem. 1998;273(20):12101-12108.

20. Oñate SA, Tsai SY, Tsai MJ, O'Malley BW. Sequence and characterization of a coactivator for the steroid hormone receptor superfamily. Science. 1995;270(5240):1354-1357.

21. Couse JF, Yates MM, Sanford R, Nyska A, Nilson JH, Korach KS. Formation of cystic ovarian follicles associated with elevated luteinizing hormone requires estrogen receptor-beta. Endocrinology. 2004;145(10):4693-4702.

22. Kusec V, Virdi AS, Prince R, Triffitt JT. Localization of estrogen receptor-alpha in human and rabbit skeletal tissues. J Clin Endocrinol Metab. 1998;83(7):2421-2428.

23. Batra GS, Hainey L, Freemont AJ, Andrew G, Saunders PT, Hoyland JA, Braidman IP. Evidence for cell-specific changes with age in expression of oestrogen receptor (ER) alpha and beta in bone fractures from men and women. J Pathol. 2003;200(1):65-73.

24. Nilsson LO, Boman A, Sävendahl L, Grigelioniene G, Ohlsson C, Ritzén EM, Wroblewski J. Demonstration of estrogen receptorbeta immunoreactivity in human growth plate cartilage. J Clin Endocrinol Metab. 1999;84(1):370-373.

25. Cui J, Shen Y, Li R. Estrogen synthesis and signaling pathways during aging: from periphery to brain. Trends Mol Med. 2013; 19(3):197-209.

26. Handa RJ, Ogawa S, Wang JM, Herbison AE. Roles for oestrogen receptor $\beta$ in adult brain function. J Neuroendocrinol. 2012;24(1): 160-173.

27. Wintermantel TM, Campbell RE, Porteous R, Bock D, Gröne HJ, Todman MG, Korach KS, Greiner E, Pérez CA, Schütz G, Herbison AE. Definition of estrogen receptor pathway critical for estrogen positive feedback to gonadotropin-releasing hormone neurons and fertility. Neuron. 2006;52(2):271-280.

28. Garcia-Segura LM, Azcoitia I, DonCarlos LL. Neuroprotection by estradiol. Prog Neurobiol. 2001;63(1):29-60.

29. Wise PM, Dubal DB, Wilson ME, Rau SW, Böttner M. Minireview: neuroprotective effects of estrogen-new insights into mechanisms of action. Endocrinology. 2001;142(3):969-973.

30. Amantea D, Russo R, Bagetta G, Corasaniti MT. From clinical evidence to molecular mechanisms underlying neuroprotection afforded by estrogens. Pharmacol Res. 2005;52(2):119-132.

31. Krezel W, Dupont S, Krust A, Chambon P, Chapman PF. Increased anxiety and synaptic plasticity in estrogen receptor beta-deficient mice. Proc Natl Acad Sci USA. 2001;98(21):12278-12282.

32. Rissman EF, Heck AL, Leonard JE, Shupnik MA, Gustafsson JA. Disruption of estrogen receptor beta gene impairs spatial learning in female mice. Proc Natl Acad Sci USA. 2002;99(6):3996-4001.

33. Kuiper GG, Enmark E, Pelto-Huikko M, Nilsson S, Gustafsson JA. Cloning of a novel receptor expressed in rat prostate and ovary. Proc Natl Acad Sci USA. 1996;93(12):5925-5930. 